\title{
Tintina Gold Province Study, Alaska and Yukon Territory, 2002-2007
}

\section{Understanding the Origin, Emplacement, and Environmental Signature of Mineral Resources}

\section{Background}

Alaska's mineral resources are as vast as the land itself. The Tintina gold province (TGP) encompasses roughly 150,000 square kilometers and is bounded on the north by the KaltagTintina fault and on the south by the Farewell-Denali fault. This is an expansive region with limited road or navigable river access. It stretches westward in a broad arc from British Columbia, Canada, through southeastern and central to southwestern Alaska, United States. The region's climate is subarctic and includes major physiographic delineations and ecoregions such as the YukonTanana upland, the Yukon River lowlands, and the Kuskokwim Mountains (Nowacki and others, 2002).

Some of the first placer and lode gold discoveries in northern North America were in the TGP in 1886. The TGP is once again the focus of a resurgence in mineral exploration, development, and mining activity. This resurgence stems from new discoveries (the Pogo and Donlin Creek deposits) as well as the application of modern extraction methods. New methods have provided access to previously known but economically restrictive resources (such as the Fort Knox-True North and Scheelite Dome deposits). In addition, the TGP hosts numerous non-gold-related mineraldeposit types.

With the exception of the recent increase in the exploration activity at the porphyry copper-gold Pebble deposit near Lake Iliamna in 2001 (fig. 1), by far, most exploration dollars spent over the past decade for the identification of new gold resources in Alaska and the Yukon Territory have been in the TGP (Hart and others, 2002).

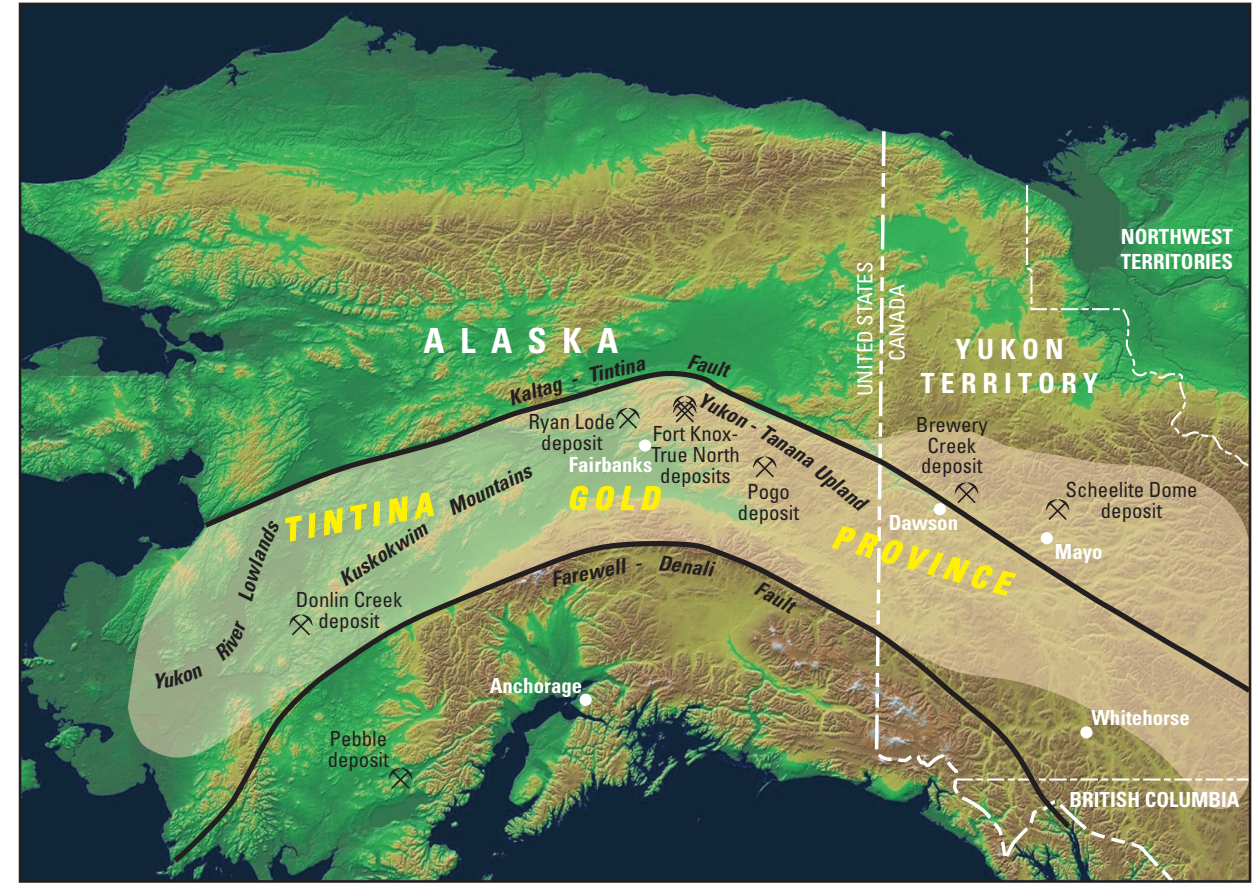

Figure 1. Landsat-based general index map of the Tintina gold province in Alaska and Canada showing seven of its major gold deposits plus the Pebble deposit (figure base, Hart and others, 2002).

The Tintina gold province is an arc-shaped 2,000-kilometer-long metallogenic province that extends from northern British Columbia, through the Yukon Territory, and across and into southwestern Alaska. In the United States, the province remains a prime area for gold exploration and includes such large gold deposits as Pogo, Fort Knox-True North, and Donlin Creek.

In recent years, gold exploration and development and mining activity have accelerated in the area. Plans have been discussed for public and private projects and infrastructures associated with development.

A U.S. Geological Survey study undertaken from 2002 to 2007 provides a context for understanding why and how the mineral resources of the area were formed, why this area is so abundantly endowed, and how the environmental signatures that are characteristic of the area are related to the development of mineral resources. Characterization of natural baseline metal concentrations in the area's watersheds is necessary to address future land-use issues related to mining and/or infrastructure activities. A thorough understanding of water-rock and elementbioavailability processes will help predict the possible environmental impact of development.

The five tasks of this study add to the science of defining and understanding an "intrusion-related gold system." 


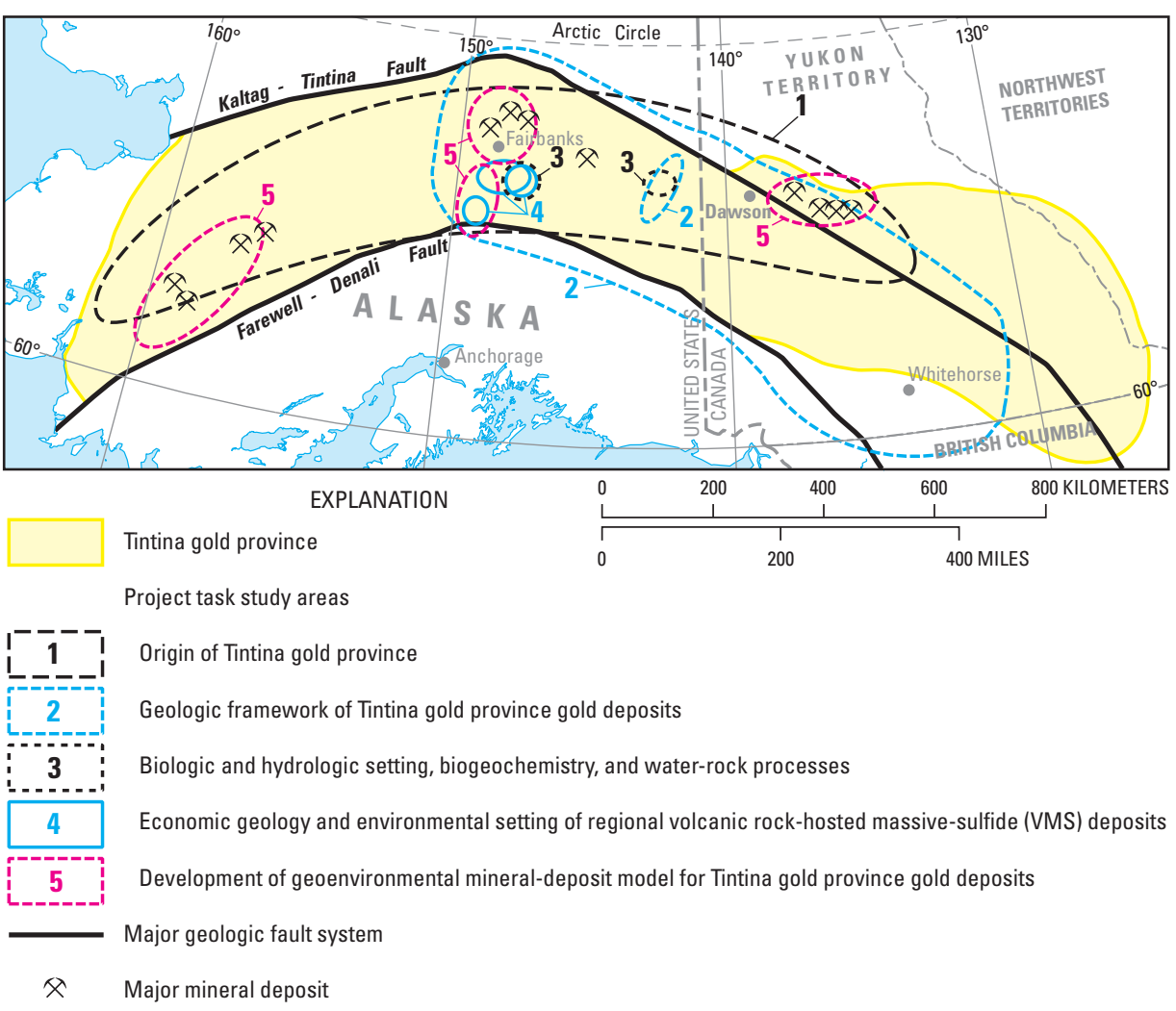

Figure 2. Tintina gold province of Alaska and the Yukon Territory.

\section{Five Tasks of the Study}

From 2002 to 2007, a U.S. Geological Survey (USGS) study of the TGP focused on the following five integrated tasks in the fields of geology, geophysics, hydrology, and geochemistry:

\section{Origin of Tintina gold province}

Understanding the origin of TGP gold deposits will help gain a fundamental scientific understanding of how these gold deposits form. In cooperation with academia and industry, this study collected and characterized ore samples from the major gold systems of the TGP, as well as barren samples of intrusive rocks associated with the ore. Detailed isotopic and geochemical studies establish possible sources for the hydrothermal fluids and associated molten rock. These results help refine the overall geneticexploration model for the epizonal gold deposits in the area. This understanding lies at the heart of ore-genesis research and helps us come to a fundamental scientific understanding of how these gold deposits form.

\section{Geologic framework of TGP gold deposits}

The framework geologic studies are key in supporting the ore-genesis research and the regional hydrologic and geoenvironmental research. Characterization of the tectonic setting and metallogeny of the Yukon-Tanana upland involved identifying the dominant structural framework in key areas. This work helps scientists understand the style and timing of tectonism and its control on plutonism and emplacement of ore-forming systems. The framework geologic studies include 1:63,360scale geologic mapping that is key in supporting the studies.

\section{Biologic and hydrologic setting, biogeochemistry, and water-rock processes}

The geochemical signature of the boreal forest, riparian, and tundra vegetation zones were studied; these are the major subarctic ecosystems that make up this region of the TGP. Characterization of the geochemical signature provides information on the extent of rock-water interactions and of element bioavailability in different geologic

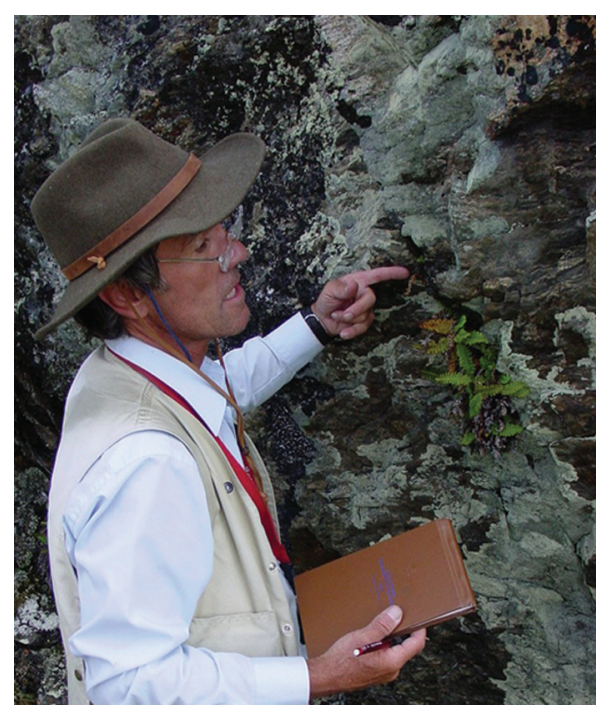

Figure 3. Field geologic observations and various geophysical investigations aid in understanding the structure and stratigraphy of bedrock and associated mineralization.

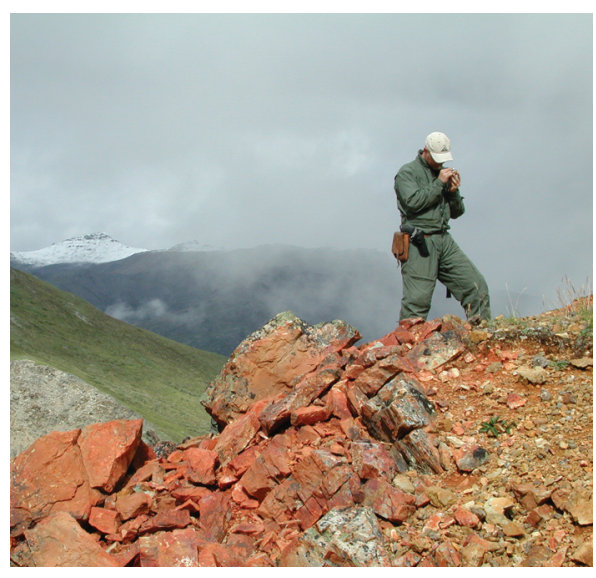

Figure 4. Altered rock (such as the reddish color) lead USGS geologists to look for mineral-rich areas.

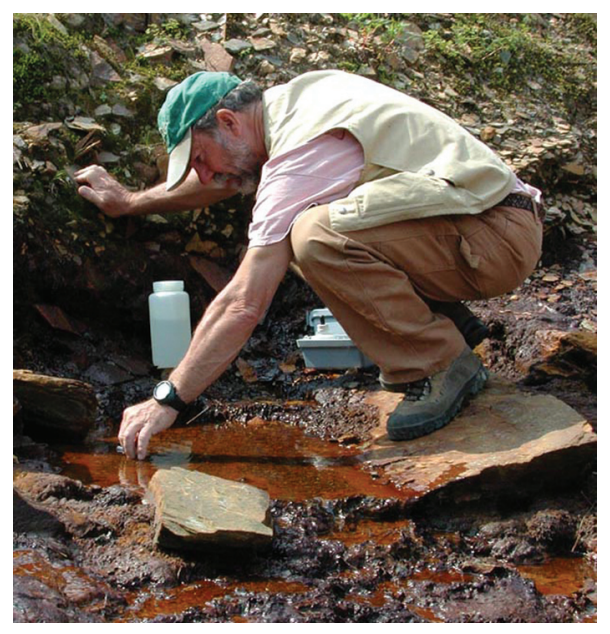

Figure 5. Acidic, metal-rich drainage is studied to define the geochemical signature and weathering behavior of undisturbed mineral deposits. 


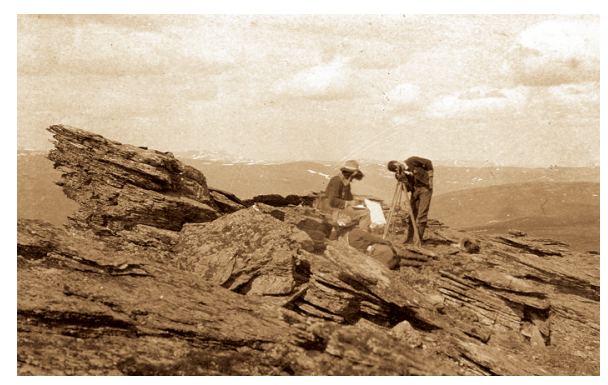

Figure 6. Historical photo of USGS survey team atop Boulder Mountain near Circle, Alaska, in the Yukon-Tanana upland (photo by W.C. Mendenhall, 1901). terranes. This includes examination of the geologic substrate (mineralized and non-mineralized) reflected in the aqueous, stream-sediment, and biogeochemical environments. Study of the extent of element bioavailability examines potential uptake by plants and animals.

\section{Economic geology and environmental setting of regional volcanic rock-hosted massive-sulfide (VMS) deposits}

Research of this type provides information for the USGS Mineral Resources Program's growing database of undeveloped mineralized areas. Defined in the study are the geology (age, whole-rock geochemistry, and tectonic setting) and metallogeny (age of ore-deposit forma- tion) of the Bonnifield mining district volcanic rock-hosted massive-sulfide deposits. This was accomplished by integrating data from industry with additional data from geochemical and stable and radiogenic isotopic studies of drill-core and surface-rock samples. Extensive investigations of the natural weathering of VMS deposits were made and the geochemical variability of selected mineralized watersheds within the Bonnifield mining district were characterized through the sampling and analysis of water, stream-sediment, and vegetation samples. These data are applied to the Mineral Resources Program's database of geoenvironmental mineral-deposit models.

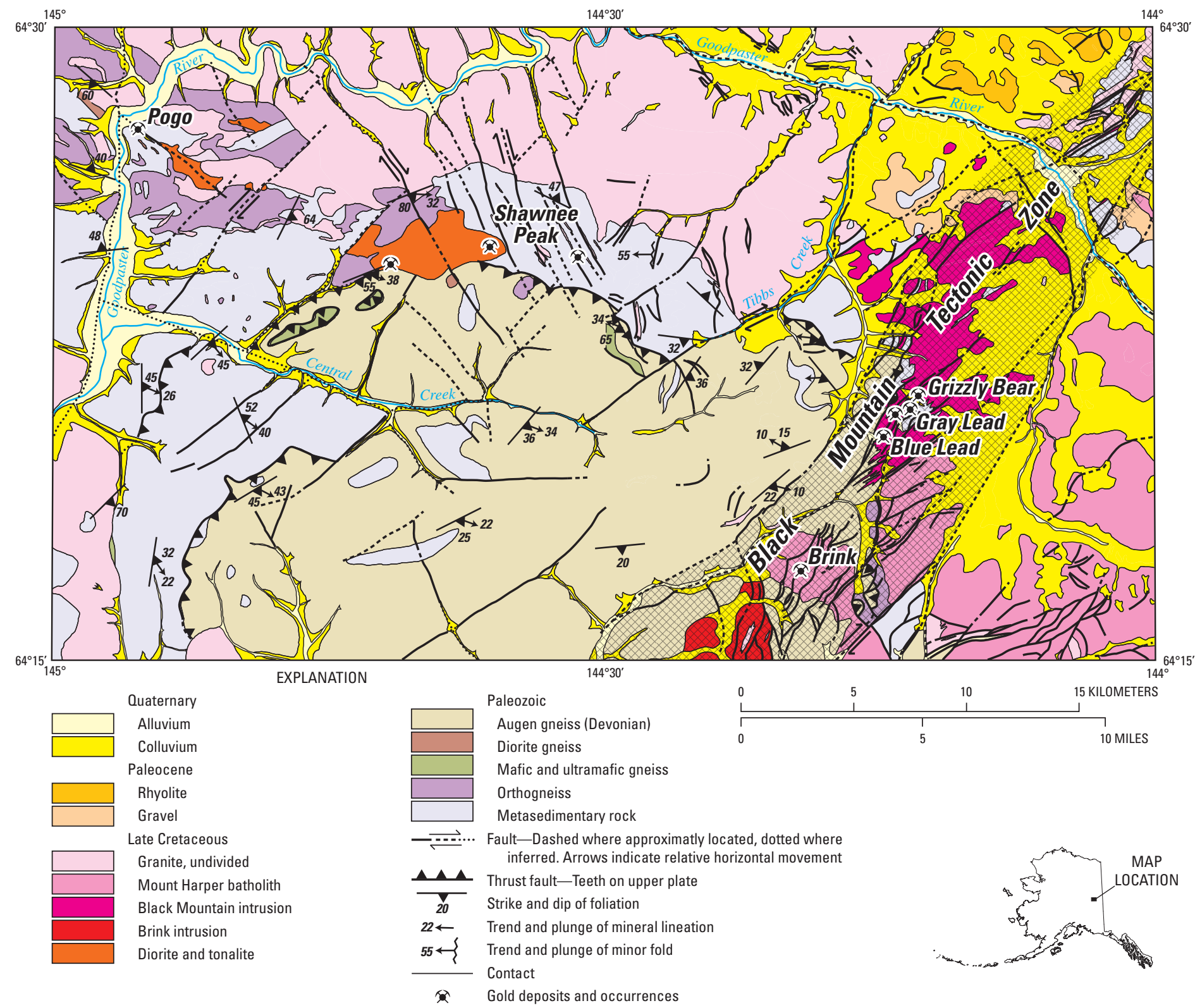

Figure 7. Many of the gold deposits and occurrences coincide with the Black Mountain tectonic zone in the Big Delta B-1 and B-2 quadrangles. The geologic mapping and investigations of the Black Mountain tectonic zone were part of the USGS 2002-2007 study (Day and others, 2007). 


\section{Development of a geoenvironmental mineral-deposit model for TGP gold deposits}

This research will help establish predevelopment geochemical baselines for rocks, soils, surface water, and vegetation in selected watersheds. A definition of the geochemical signature of ore deposits characteristic of the TGP (Brewery Creek, Fort Knox-True North, Ryan Lode, and Donlin Creek deposits) has been developed.

The epizonal-type deposits require environmental considerations, and predevelopment geochemical background and baseline information (especially for arsenic, mercury, and antimony levels in soils and waters) have been established. This information is critical for resource development and land management.

\section{For More Information}

The TGP study addresses specific USGS and national goals related to mineral resources, including ensuring the availability of reliable geologic, geochemical, geophysical, and mineral locality data for the Nation. Since the inception of the TGP study in 2002, more than 40 reports and numerous presentations have been published. Many of these can be accessed through the following Web-based links:

USGS Tintina Gold Province Project Web Site: http://minerals.usgs.gov/east/ tintina/index.html

USGS Mineral Resources Program Web Site: http://minerals.usgs.gov/ By Larry P. Gough (lgough@usgs.gov) and Warren C. Day (wday@usgs.gov)

\section{References}

Day, W.C., O'Neill, J.M., Aleinikoff, J.N., Green, G.N., Saltus, R.W., and Gough, L.P., 2007, Geologic map of the Big Delta B-1 quadrangle, eastcentral Alaska: U.S. Geological Survey Scientific Investigations Map 2975, pamphlet 23 p., 1 plate, scale 1:63,360, available online at http://pubs.usgs. gov/sim/2007/2975/.

Hart, C.J.R., McCoy, D.T., Goldfarb, R.J., Smith, Moira, Roberts, Paul, Hulstein, Roger, Bakke, A.A., and Bundtzen, T.K., 2002, Geology, exploration, and discovery in the Tintina gold province, Alaska and Yukon: Society of Economic Geologists, Special Publication 9, p. 241-274.

Nowacki, Gregory, Spencer, Page, Fleming, Michael, Brock, Terry, and Jorgenson, Torre, 2002, Unified ecosystems of Alaska, 2001: U.S. Geological Survey Open-File Report 02-297, map scale 1:4,000,000.

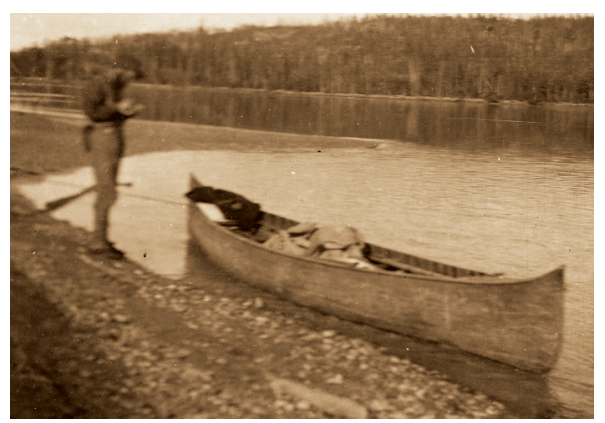

Figure 8. USGS geologist Alfred H. Brooks and canoe near what would become the Bonnifield mining district, Alaska, August 27, 1898. Current studies in the TGP reflect the long-time interest of USGS scientists in this area (photo credited to Alfred H. Brooks).

\section{Cooperating Agencies, Organizations, and Industries}

We are deeply indebted to the contribution of our collaborators from government agencies as well as from academia and industry.

Alaska Department of Environmental Conservation

Alaska Department of Natural Resources

-Division of Geological \& Geophysical Surveys

-Division of Mining, Land \& Water

-Division of Forestry

Avalon Energy Corporation

Bureau of Land Management

Calista Corporation

Doyon, Limited

Fairbanks Gold Mining, Inc.

Grayd Resource Corporation

GW Scientific

National Park Service

-Denali National Park \& Preserve

-Yukon-Charley Rivers National Preserve

NovaGold Resources Inc.

Pacific Alaska Resources Company

Pacific Rim Geological Consulting, Inc.

Teck Cominco Limited

The University of Western Australia

TNR Resources Ltd.

University of Alaska Anchorage

University of Alaska Fairbanks

University of Colorado at Boulder

U.S. Department of Agriculture

-Natural Resources Conservation Service

U.S. Geological Survey

-Mineral Resources Program

Yukon Geological Survey 